\title{
EFFECT OF CURING ON THE QUALITY OF BEEF AND BUFFEN
}

\author{
R. Islam ${ }^{1}$, M. M. Hossain ${ }^{1}$, S. Akhter ${ }^{1}$ and M. A. Malek ${ }^{2}$
}

\begin{abstract}
The study was conducted to investigate the effect of curing on the quality of beef and buffen and also to find out the relationship between the quality of beef and buffen with their storage time. Six treatments of which three from beef were taken as dry salt cured beef $\left(A_{1}\right)$, dry sugar cured beef $\left(A_{2}\right)$, brine cured beef $\left(A_{3}\right)$ and three from buffen as dry salt cured buffen $\left(A_{4}\right)$, dry sugar cured buffen $\left(A_{5}\right)$ and brine cured buffen $\left(A_{6}\right)$. These samples were cured at room temperature for 10 days and then dried. The dried sample was stored for 120 days and analyzed on first day, $30^{\text {th }}$ day, $60^{\text {th }}$ day and $120^{\text {th }}$ day. The quality of cured meat samples were studied by chemical analysis. All the samples were acceptable up to the end of the storage time. Dry matter, ash, crude protein and ether extract of all the samples decreased gradually with elapse of storage time. The initial (0 day) dry matter, ash, crude protein and ether extract content of the samples were ranged from 98.00$99.10 \%, 13.07-15.33 \%, 75.01-81.07 \%$ and $3.70-5.50 \%$, respectively and the end of 120 days of storage the dry matter, ash, crude protein and ether extract content of the samples ranged from $89.50-90.50 \%, 12.80-14.802 \%, 73.68-74.97 \%$ and $3.35-4.25 \%$, respectively. Statistical analysis indicated that with the elapse of storage time quality parameters of meat samples decreased significantly $(P<0.01)$. Quality parameters also varied among the samples. A significant difference exists in species when considering the value of fat. The relationship between the quality of beef and buffen shows that dry matter and crude protein are highly significant $(P<0.01)$, ether extract is significant $(P<0.05)$ and ash was statistically not significant with their storage times. Although the values are non significant, the loss of protein was lower in brine cured meat than other sample. It may be concluded that, brine curing could be a useful technique for beef and buffen preservation.
\end{abstract}

Key words: Curing, Beef, Buffen, Preservation

\section{Introduction}

Curing is one of the suitable methods of meat preservation. It is simply to preserve meats using salt or a salt brine, with or without spices, sugar, nitrates, and other ingredients. In Bangladesh, the process of curing can easily perform by the village women who are mostly illiterate and have no scientific knowledge about its quality. Water inside the meat spells trouble, it spoils everything and eliminating it by salting and drying allows meat to be stored for longer periods of time. In its simplest form is adding

1 Department of Animal Science, Bangladesh Agricultural University (BAU), Mymensing-2202. (mmh_bau2009@yahoo.com)

2 Program Supervisor, Food Security Program, Action against Hunger (France), Borguna base office, Borguna, Bangladesh

(Received: May 19, 2009) 
salt in the right concentration to meat and drawing moisture out of it what subsequently destroys or inactivates the growth of microorganisms (FAO, 1994). Briefly, curing results from the combined actions of salt, sugar, and nitrate (sodium nitrate or saltpeter) on the meat. Salt inhibits the growth of bacteria and, in some meat products, works best with nitrate. Sugar adds flavor and helps reduce the harshness of salt in cured meat. Sugar also acts as an energy source for useful bacteria in making some cured products. Potassium nitrate (salt peter) or sodium nitrate kills dangerous bacteria in the cured meat, gives cured meat its characteristic flavor and reddish-pink color, and helps prevent rancidity. So, the proper curing techniques are essential considering the environmental condition and places in our country, which will provide the nutrient contents and other factors that are associated with the quality of meat in a good amount and proportion. Using proper curing method of preservation it would be possible to control spoilage of meat, to preserve surplus meat and to increase shelf life of meat (Akbar, 2008). Curing is the suitable method for preservation for future use, unfortunately there is no baseline information on the suitable method of meat preservation of Bangladesh. Based on the present need of the country, study is needed to determine the relationship between storage time and different parameters of cured beef and buffen. The present study was, therefore, undertaken to find out the effect of curing on the quality of beef and buffen.

\section{Materials and Methods}

\section{Collection and sample preparation}

Raw and boneless buffen and fresh and boneless beef was bought from the butcher shop and then brought into the laboratory for processing. Then Six samples of beef and buffen were prepared for this experiment. All visible fat, bone and connective tissue were trimmed off as far as possible with the help of knife and the sample was cut into small pieces. Buffalo meat and cattle meat were divided into two parts each differently which were equal in amount. For the preparation of treatment, one part of beef as well as one part of buffen was washed properly with clean water and made water free by pressing with hand. Meat piece of all parts of animal were mixed thoroughly for sample preparation. For this purpose six treatments of which three from beef were taken as dry salt cured beef $\left(A_{1}\right)$, dry sugar cured beef $\left(A_{2}\right)$, brine cured beef $\left(A_{3}\right)$ and three from buffen as dry salt cured buffen $\left(A_{4}\right)$, dry sugar cured buffen $\left(A_{5}\right)$ and brine cured buffen $\left(A_{6}\right)$.

\section{Curing agents and duration}

Sodium chloride, sugar, potassium nitrate and distilled water were used as curing agents. The reagents weighed at different level as $8 \%$ salt and $0.125 \%$ potassium nitrate for dry salt curing; $8 \%$ salt, $2 \%$ sugar and $0.125 \%$ potassium nitrate for dry sugar curing and $8 \%$ salt, $2 \%$ sugar, $0.125 \% \mathrm{KNO}_{3}$ and $59.5 \%$ water for brine curing. All the samples were subjected to curing in the month of summer when relative humidity was 
$65-70 \%$ for 10 days at normal room temperature. Stored samples were observed at 0 , 30,60 and 120 days at 120 days of total storage period.

\section{Dry salt, sugar and brine curing}

Salt, sugar, $\mathrm{KNO}_{3}$ and water were mixed with the meat samples. After proper mixing the samples were taken into 6 separate jars for beef and buffen. Daily intercultural practices such as moving, enclosing and opening the cover, stirring of meat pieces were done everyday. At $10^{\text {th }}$ day, all samples were removed from the jar and dried them into the oven at $55^{\circ} \mathrm{C}$ until the moisture was completely removed.

\section{Storage of the sample}

The samples were stored in polyethylene bags separately. Then the samples were stored at room temperature during 120 days of experimental period for further analysis.

\section{Proximate composition}

Proximate composition analysis such as moisture, ether extract, crude protein and ash were carried out according to the methods (AOAC, 2003) with certain modifications.

\section{pH measurement}

The $\mathrm{pH}$ value of meat was measured once daily by using $\mathrm{pH}$ meter (Corning model 250) from meat homogenate. The homogenate was prepared by blending $2 \mathrm{~g}$ of meat with 10 $\mathrm{ml}$ distilled water. The $\mathrm{pH}$ value of brine cured sample was recorded day by day during the time of curing (10 days).

\section{Statistical analysis}

Data were analyzed statistically using the analysis of variance technique in a computer using MSTAT statistical computer package programme in accordance with the principle of Completely Randomized Design (CRD) Duncan's new Multiple Range Test (DMRT) was done to compare variations between treatments where ANOVA showed significant differences. SEM values were calculated to identify differences between means. The effect among treatments and levels was done by factorial experiment.

\section{Results and Discussion}

\section{Proximate composition of meat Dry matter}

The initial dry matter value was in the range of $98.00 \pm 2.0$ to $99.10 \pm 0.1 \%$ and at the end of 120 days of storage the dry matter value ranged from $89.50 \pm 2.0$ to $90.50 \pm$ $0.8 \%$. Dry matter content decreased with the increase of storage time in all samples. The loss of moisture probably associated to decreased dry matter. The same trend was also observed by Konieczny et al. (2007) and they reported that dry matter content decreased during storage period. Dry matter may be decreased for the passes of water with the increase of storage time. 
Bang. J. Anim. Sci. 2009, 38(1\&2)

\section{Ash}

The initial value of ash ranged from $13.07 \pm 1.02$ to $15.33 \pm 2.2 \%$ and at the final value was $12.80 \pm 2.2$ to $14.80 \pm 1.72 \%$. The ash value decreased with the storage time. The value was comparatively higher in the sugar cured meat and may be due to the penetration of sugar in meat tissue and diffusion of moisture from the tissue was higher. The value was comparatively lower in the brine cured meat and may be due to the penetration of salt in meat and absorption of moisture from the tissue.

\section{Crude protein}

The initial protein content was in the range of $75.01 \pm 1.01$ to $81.07 \pm 1.0 \%$ and at the end of 120 days of storage protein values were in the range of $73.68 \pm 1.2$ to $74.97 \pm$ $0.98 \%$. The protein content decreased with the increase of storage time. The loss of protein during storage in those samples may be related with loss of sarcoplasmic protein and poor water holding capacity. Sarcoplasmic protein may be lost during storage in the form of drip loss. The result was supported by Wang et al. (1997). Konieczny et al. (2007) investigated that protein content of beef decreased during storage that support the present result. The increases in crude protein content in salt and brine cured meat compared to sugar cured meat may be due to increases NPN content with the elapse of storage time. The above results indicate that salt and brine cured product may be better than sugar cured product when their protein content was considered.

\section{Ether extract}

The initial EE content was in the range of $3.70 \pm 0.2$ to $5.50 \pm 0.5 \%$ and EE value gradually decreased with the elapse of storage time. At the end of 120 days of storage, the values were in the range of $3.35 \pm 0.2$ to $4.25 \pm 0.2 \%$. According to Kleveran et al. (1965) incorporation of salt, sugar and brine in the meat led to increase oxidation. They observed that lipolysis takes place during curing which decreases the ether extract content in meat. The rapid decrease of EE content probably associated with the presence of potassium nitrate.

\section{Effect of curing methods on treated samples on different parameters}

The Table 1 reveals that the DM percentage of all the samples were statistically not significant similar with each other. The ash percentage of the sample $A_{1}, A_{2}, A_{3}, A_{4}, A_{5}$ and $M_{6}$ differ significantly $(P<0.01)$. Percentage of crude protein content was maximum (77.23\%) in $A_{3}$ and minimum $(74.67 \%)$ in $A_{5}$. Crude protein percentage of all the sample was non-significant $(P>0.01)$. Maximum fat content was found $4.76 \%$ in $A_{5}$ and minimum $3.50 \%$ in $A_{4}$. Fat content of all the samples were statistically significant to each other $(P<0.01)$.

\section{Effect of curing time on different parameters}

The initial dry matter was $98.60 \%$. After 120 days this value reached up to $90.00 \%$. This lower value may be due to post mortem drip loss after thawing. The results support the findings of Szmanko et al. (1997) who found similar result in pork. The dry matter 
percentage was also significantly different $(P<0.01)$. The initial ash was $14.47 \%$. At the end of storage this value changed to $13.96 \%$. The ash content of the meat sample was non-significant $(P>0.01)$ from each other at different time. The initial fat was $4.48 \%$. After 120 days this value changed to $3.80 \%$ (Table 2). The fat content of the meat sample was significant $(P>0.01)$ from each other at different time. The initial crude protein was $78.40 \%$. At the end of 120 days this value reached to $74.33 \%$. The crude protein content of the meat sample significantly differed $(P<0.01)$ from each other at different time. Protein content may be lost during curing period. The results obtained from the present study are supported by Sarma et al. (1994) and Wang et al. (1997).

Table 1. Effect of curing methods on treated samples on different parameters (\%)

\begin{tabular}{|c|c|c|c|c|c|c|c|c|}
\hline \multirow{2}{*}{$\begin{array}{l}\text { Parameters } \\
(\mathrm{g} / 100 \mathrm{~g})\end{array}$} & \multicolumn{6}{|c|}{ Treatments $^{\#}$} & \multirow{2}{*}{ SEM } & \multirow{2}{*}{ Level of sig. } \\
\hline & $A_{1}$ & $A_{2}$ & $A_{3}$ & $A_{4}$ & $A_{5}$ & $A_{6}$ & & \\
\hline DM & 93.93 & 93.20 & 93.53 & 94.03 & 94.25 & 93.83 & 0.71 & NS \\
\hline Ash & $14.63^{b}$ & $14.74^{\mathrm{ab}}$ & $13.04^{c}$ & $14.69^{a b}$ & $15.03^{\mathrm{a}}$ & $13.00^{\mathrm{C}}$ & 0.18 & $\star \star$ \\
\hline $\mathrm{CP}$ & 76.88 & 76.40 & 77.23 & 76.02 & 74.67 & 76.17 & 0.40 & NS \\
\hline EE & $3.56^{\mathrm{b}}$ & $4.00^{b}$ & $4.64^{\mathrm{a}}$ & $3.50^{b}$ & $4.76^{\mathrm{a}}$ & $4.09^{b}$ & 0.12 & ** \\
\hline
\end{tabular}

${ }^{\#} A_{1}=$ Dry salt cured beef, $A_{2}=$ Dry sugar cured beef, $A_{3}=$ Brine cured beef, $A_{4}=$ Dry salt cured buffen, $A_{5}=$ Dry sugar cured buffen, $A_{6}=$ Brine cured buffen

NS = means not significant

** Significant at $1 \%$ level

${ }^{\mathrm{abc}}$ Mean with different superscripts within same row differ significantly, $\mathrm{P}<0.01$

Table 2. Effect of curing time on different parameters (\%)

\begin{tabular}{|l|c|c|c|c|c|c|}
\hline \multirow{2}{*}{$\begin{array}{c}\text { Parameters } \\
(\mathbf{g} / \mathbf{1 0 0 g})\end{array}$} & $\mathbf{0}$ & $\mathbf{3 0}$ & $\mathbf{6 0}$ & $\mathbf{1 2 0}$ & \multirow{2}{*}{ SEM } & \multirow{2}{*}{ Level of sig. } \\
\cline { 2 - 5 } & $\mathbf{0}$ & $95.18^{\mathrm{b}}$ & $91.38^{\mathrm{c}}$ & $90.00^{\mathrm{d}}$ & 0.707 & $* \star$ \\
DM & $98.60^{\mathrm{a}}$ & 14.23 & 14.10 & 13.96 & 0.180 & $\mathrm{NS}$ \\
CP & 14.47 & $77.04^{\mathrm{a}}$ & $75.15^{\mathrm{b}}$ & $74.33^{\mathrm{b}}$ & 0.399 & $\star *$ \\
EE & $78.40^{\mathrm{a}}$ & 4.21 & 3.88 & 3.80 & 0.121 & $\mathrm{NS}$ \\
\hline
\end{tabular}

NS = means not significant

** Significant at $1 \%$ level

${ }^{\mathrm{abc}}$ Mean with different superscripts within same row differ significantly, $\mathrm{P}<0.01$

\section{The interaction effect of storage time and meat sample}

The results indicated that with the increase of storage time the quality parameters of meat sample decreased.

\section{Effect of species on different parameters}

The dry matter content of beef $\left(A_{1}\right)$ and buffen $\left(A_{4}\right)$ were 93.93 and 94.03 , respectively irrespective of storage times and showed non significant difference $(P>0.01)$ (Table 4$)$. In some cases dry matter, crude protein and ash are significant and in some cases 
Bang. J. Anim. Sci. 2009, 38(1\&2)

insignificant (Akbar, 2008). It may be due to experimental error and random sampling. Dry matter content was more in salt and brine cured samples than that in sugar cured beef and buffen. Sugar cured beef and buffen showed that the loss of dry matter was more. In case of fat and protein, it was observed that less loss of nutrient was in beef than that of buffen. In every cases of sugar cured beef and buffen, both beef and buffen are significant $(P<0.01)$. Highly significant difference exists in species when considering fat $(P<0.01)$. Although the values are statistically insignificant, protein content was higher in beef rather than buffen. Therefore, beef is high quality than buffen showed after curing by maintaining its quality up to 120 days of storage.

\section{Relationship between storage time and different parameters}

This section deals with the relationship among the different parameter and the storage time. Each of the parameter constituted an independent variable while time was the dependent variable of the study. Coefficient of Determination $\left(R^{2}\right)$ has been used to test the hypothesis concerning the, relationship between two variables and 0.05 level of' significance carts rued as the basis for acceptance or rejection of a hypothesis. The summary of the results of' the coefficient of determination regarding relationship between the different parameter and time has been presented in Table 3 .

Table 3. Interaction effect of storage time and meat sample

\begin{tabular}{|c|c|c|c|c|c|c|c|c|c|}
\hline \multirow{2}{*}{$\begin{array}{c}\text { Parameter } \\
\text { (\%) }\end{array}$} & \multirow{2}{*}{ Periods } & \multicolumn{6}{|c|}{ Treatments $^{\#}$} & \multirow{2}{*}{ SEM } & \multirow{2}{*}{$\begin{array}{l}\text { Level of } \\
\text { sig. }\end{array}$} \\
\hline & & A1 & A2 & A3 & A4 & A5 & A6 & & \\
\hline \multirow{4}{*}{ DM } & 0 & 98.4 & 98.4 & 98 & 99 & 99.1 & 98.7 & 0.294 & NS \\
\hline & 30 & 95.2 & 94.8 & 94.9 & 95.7 & 95.4 & 95.1 & 0.366 & NS \\
\hline & 60 & 91.8 & 90.1 & 91.4 & 91.2 & 92.0 & 91.8 & 0.279 & NS \\
\hline & 120 & 90.3 & 89.5 & 89.8 & 90.2 & 90.5 & 89.7 & 0.338 & NS \\
\hline \multirow{4}{*}{ Ash } & 0 & 14.84 & 15.14 & 13.37 & 15.05 & 15.33 & 13.07 & 0.343 & NS \\
\hline & 30 & 14.7 & 14.66 & 13.07 & 14.83 & 15.09 & 13.03 & 0.381 & NS \\
\hline & 60 & 14.59 & 14.76 & 12.91 & 14.47 & 14.89 & 12.96 & 0.328 & NS \\
\hline & 120 & 14.39 & 14.41 & 12.8 & 14.41 & 14.8 & 12.93 & 0.372 & NS \\
\hline \multirow{4}{*}{$\mathrm{CP}$} & 0 & $79.81^{\mathrm{ab}}$ & $77.67^{b}$ & $81.07^{\mathrm{a}}$ & $78.13^{\mathrm{ab}}$ & $75.01 \mathrm{c}$ & $78.69^{\mathrm{ab}}$ & 0.537 & $\star \star$ \\
\hline & 30 & 77.43 & 77.37 & 77.4 & 77.29 & 75.36 & 77.37 & 0.427 & NS \\
\hline & 60 & 75.44 & 75.59 & 75.74 & 74.7 & 74.62 & 74.78 & 0.336 & NS \\
\hline & 120 & 74.84 & 74.97 & 74.72 & 73.96 & 73.68 & 73.83 & 0.288 & NS \\
\hline \multirow{4}{*}{ Fat } & 0 & $3.75^{c}$ & $4.1 a^{b}$ & $5.3^{\mathrm{a}}$ & $3.7^{\mathrm{C}}$ & $5.5^{\mathrm{a}}$ & $4.5^{b}$ & 0.180 & $\star \star *$ \\
\hline & 30 & $3.65^{c}$ & $4.05^{b}$ & $4.96^{\mathrm{a}}$ & $3.6^{c}$ & $4.95^{\mathrm{a}}$ & $4.04^{b}$ & 0.136 & $\star *$ \\
\hline & 60 & $3.45^{c}$ & $3.95^{b}$ & $4.25^{a}$ & $3.35^{c}$ & $4.35^{\mathrm{a}}$ & $3.95^{b}$ & 0.095 & $\star *$ \\
\hline & 120 & $3.4^{c}$ & $3.9^{b}$ & $4.05^{\mathrm{ab}}$ & $3.35^{c}$ & $4.25^{\mathrm{a}}$ & $3.85^{b}$ & 0.086 & $\star *$ \\
\hline
\end{tabular}

${ }^{\#} A_{1}=$ Dry salt cured beef, $A_{2}=$ Dry sugar cured beef, $A_{3}=$ Brine cured beef, $A_{4}=$ Dry salt cured buffen, $A_{5}=$ Dry sugar cured buffen, $A_{6}=$ Brine cured buffen

NS $=$ Not significant

** Significant at $1 \%$ level

${ }^{\mathrm{abc}}$ Mean with different superscripts within same row differ significantly 


\section{Relationship between dry mater and storage time}

The relationship between dry mater and storage time was examined. The result revealed that the computed " $\mathrm{R}^{2 \text { " }}$ value for the storage time was $0.8588^{\star *}$ indicating that the relationship between dry mater and storage time were highly significant at 0.01 level of probability (Fig. 1). Therefore, it was concluded that dry mater had highly significant positive relationship with the storage time (Malek, 2008).

\section{Relationship between ash and storage time}

The relationship between ash and storage time was examined. The result revealed that computed " $\mathrm{R}^{2 \text { " }}$ value for the storage time was $0.0434^{\mathrm{NS}}$ (Fig. 2). The relationship between ash and storage time were statistically insignificant. Therefore, it was concluded that the ash had insignificant positive relationship with the storage time (Malek, 2008).

Table 4. Effect of species on different parameters

\begin{tabular}{|c|c|c|c|c|c|}
\hline $\begin{array}{c}\text { Parameters } \\
\text { (\%) }\end{array}$ & Samples & Beef & Buffen & P-Value & Level of sig. \\
\hline \multirow{3}{*}{ DM } & $\mathrm{A}_{1}$ and $\mathrm{A}_{4}$ & 93.93 & 94.03 & 0.745 & NS \\
\hline & $A_{2}$ and $A_{5}$ & 93.20 & 94.25 & 0.038 & * \\
\hline & $A_{3}$ and $A_{6}$ & 93.53 & 93.83 & 0.173 & NS \\
\hline \multirow{3}{*}{ Ash } & $A_{1}$ and $A_{4}$ & 14.63 & 14.69 & 0.463 & NS \\
\hline & $A_{2}$ and $A_{5}$ & 14.74 & 15.03 & 0.031 & * \\
\hline & $A_{3}$ and $A_{6}$ & 13.04 & 12.99 & 0.697 & NS \\
\hline \multirow{3}{*}{$\mathrm{CP}$} & $A_{1}$ and $A_{4}$ & 76.88 & 76.02 & 0.073 & NS \\
\hline & $A_{2}$ and $A_{5}$ & 76.40 & 74.67 & 0.020 & * \\
\hline & $\mathrm{A}_{3}$ and $\mathrm{A}_{6}$ & 77.23 & 76.17 & 0.116 & NS \\
\hline \multirow{3}{*}{ EE } & $A_{1}$ and $A_{4}$ & 3.56 & 3.50 & 0.015 & * \\
\hline & $A_{2}$ and $A_{5}$ & 4.00 & 4.76 & 0.053 & * \\
\hline & $A_{3}$ and $A_{6}$ & 4.64 & 4.09 & 0.053 & * \\
\hline
\end{tabular}

Significant at $5 \%$ level, NS = means not significant

\section{Relationship between crude protein and storage time}

The relationship between crude protein and storage time was examined. The result shows that the computed value of " ${ }^{2 "}$ " for the storage time were $0.6202^{\star \star}$ (Fig. 3). The relationship between crude protein and storage time were highly significant at 0.01 level of probability. Therefore, it was concluded that crude protein had a highly significant positive relationship with storage time (Malek, 2008).

\section{Relationship between ether extract and storage time}

The relationship between Ether Extract and storage time was examined. The result 


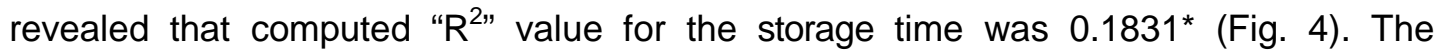
relationship between Ether Extract and storage time were significant of 0.05 level of probability. Therefore, it was concluded that the Ether Extract had a significant positive relationship with storage time.

\section{$\mathrm{pH}$ measurement of brine cured meat}

The $\mathrm{pH}$ value of beef and buffen is shown in Table 5 . The initial $\mathrm{pH}$ value of beef and buffen (as fresh sample) was 5.82 and 5.56, respectively like as Hamid et al., 2008. The results showed that rapidly declines the $\mathrm{pH}$ value just after mixing the curing agents as 3.93 and 3.81 and showing a continuous increase in $\mathrm{pH}$ as 5.23 and 4.69 for beef and buffen, respectively which was similar to Xu et al., 2006. They showed that the initial $\mathrm{pH}$ value was more than 6 and after mixing the curing agent its declines to 4.89 and then increase up to 5.79 which is similar to beef and slightly higher than buffen.

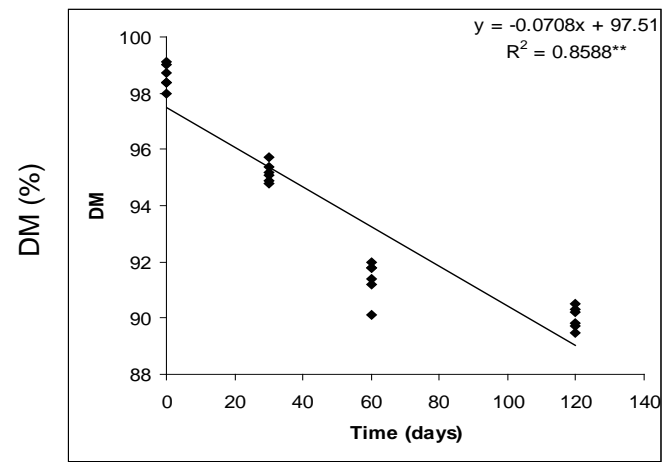

Fig. 1. Relationship between dry mater and storage time

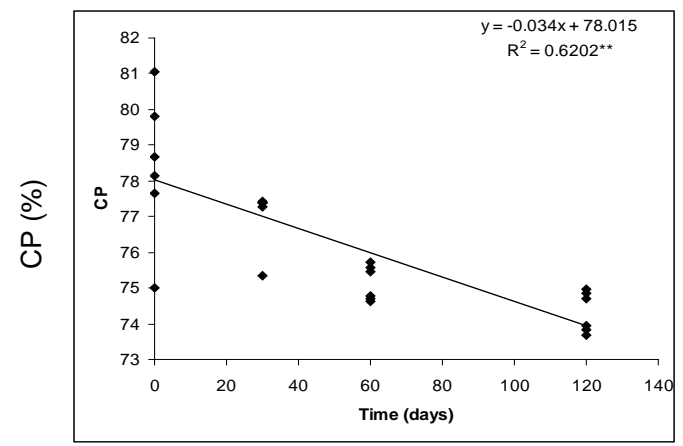

Fig. 3. Relationship between crude protein and storage time

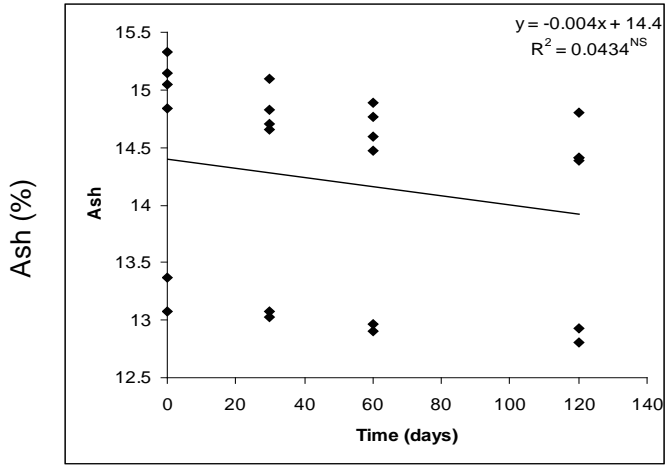

Fig. 2. Relationship between ash and storage time

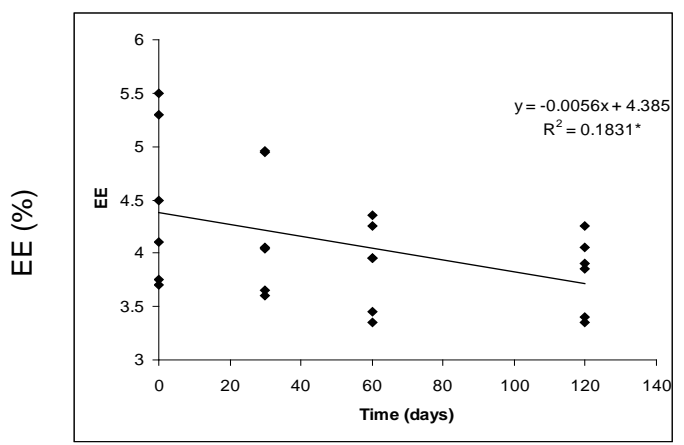

Fig. 4. Relationship between ether extract and storage time 
Table 5. pH of brine cured meat

\begin{tabular}{|c|c|c|}
\hline Days & Beef & Buffen \\
\hline 1 & $5.82++$ & $5.56++$ \\
2 & $3.93+$ & $3.81+$ \\
3 & $4.10+$ & $3.96+$ \\
4 & $4.25+$ & $4.10+$ \\
5 & $4.41+$ & $4.22+$ \\
6 & $4.56+$ & $4.32+$ \\
7 & $4.63+$ & $4.40+$ \\
8 & $4.92+$ & $4.58+$ \\
9 & $5.10+$ & $4.66+$ \\
10 & $5.23+$ & $4.69+$ \\
\hline
\end{tabular}

$++\mathrm{pH}$ of fresh beef and buffen sample (First day $\mathrm{pH}$ reading before curing)

$+\mathrm{pH}$ reading after curing of beef and buffen

\section{Conclusion}

From the present study it can be concluded that nutrient content of meat is closely related with the storage time and brine curing is the best method of beef and buffen preservation.

\section{Literature Cited}

Akbar, M. A. 2008. Effect of sun heating on fresh or cured cattle and goat meat. MS Thesis. Department of Animal Science. Bangladesh Agricultural University, Mymensingh.

Alam, J. 1993 Livestock-the sector for more investment in Bangladesh. Asian Livestock, 18(7): 77-81.

Alam, J. 1995. Livestock resource of Bangladesh. Present Status and Future Potential, University Press Limited. Dhaka Bangladesh.

AOAC (Association of Official Analytical Chemist). 2003. Horwitz, W. (ed.), Official Methods of Analysis, Association of Official Analytical Chemist. $17^{\text {th }}$ ed., Washington, DC, USA.

BBS, 2005. Statistical year book of Bangladesh. Bangladesh Bureau of Statistics. Ministry of Planning, Planning Division, Government of the Peoples Republic of Bangladesh.

Chawdhury, S. D., Latif, M. A. and Debnath, S. C. 1993. Appropriate level of education for trainers in backyard poultry raisers training program as determined by their performance. International Journal of Animal Science, 8: 23-26.

FAO (Food and Agriculture Organization of United Nations). 1994. Manual on Simple Methods of Meat Preservation. Animal Production and Health Paper No. 79. Rome, Italy.

FAO (Food and Agriculture Organization of United Nations). 2006. Production Year Book, 50. Rome, Italy.

Fennema, O. R. 1975. Introduction to food preservation. In: Principles of food science. (Ed. O. R. Fennema). Marcel Dekker, Inc. New York. pp. 1-7.

Fidanza, F. 1982. Nutritional characteristics of meat from buffalo. In: caserta zoootecnica Assoc. Allevatori (CE), caserta. Italy, 6: 1-6. 
Bang. J. Anim. Sci. 2009, 38(1\&2)

Hamid, M. A. S. Akhter, Rahman, S. M. E. and Khan, M. 2008. Effect of age and wholesale cuts on the quality of indigenous sheep carcass. Bangladesh Journal of Animal Science. 37(1) : 32-38.

Kleveran, J. and Legendre, R. 1965. Private communication. In Fish as Food; vol. III. Ed. G. Borgstorm. Academic Press. New York. p. 133-160.

Konieczny, P., Stangierski, J. and Kijowski, J. 2007. Physical and chemical characteristics and acceptability of home style beef jerky. Meat Science, 76(2): 253-257.

Lapitan, R. M., Del Bario, A. N., Katsube, O., Orden, E. A., Robles, A. Y., Fujihara, T., Cruz and L. C., Kanai. Y. 2004. Proceeding $7^{\text {th }}$ World Buffalo congress, Makati city, Philippines, pp. 202-211.

Malek, M. A., Hossain, M. M., Islam, R. and Akhter, S. 2009. Methods of drying beef and buffalo meat on meat quality. The Bangladesh Veterinarian, 26(1): 31-38.

Moran, J. B. 1986. Comparative performance of five genotype of Indonesian large ruminants. III, Growth and development of carcass tissues. Australian Journal of Agricultural Research, 37:435-447.

Sarma, J., Srikar, L. N. and Reddy, J. V. S. 1994. Deteriorative changes in ice stored pink perch and oil sardine. Indian Journal of Marine Sciences, 12(4): 921-925.

Szmanko, T., Honikel, K. O. and Hofmann, K. 1997. Changes in histological structure and physicochemical properties of raw, cured, smoked pork loins resulting from freezing near cyroscopic temperature. Food Science and Tech. Abstract. 29(1): 247.

Wang, B. W., Xiong, Y. L. L., Srinivasan, S. (1997). Chemical stability of antioxidant-washed beef heart surimi during frozen storage Journal of Food Science, 62: 939-945.

Xu, B. C., Liu, Z. W., Ren, F. Z. and Sun, Y. 2006. Effects of natural preservative and modified atmosphere packaging on shelf-life of sliced beef ham. Transactions of the Chinese Society of Agricultural Engineering, 22(3): 143-147. 